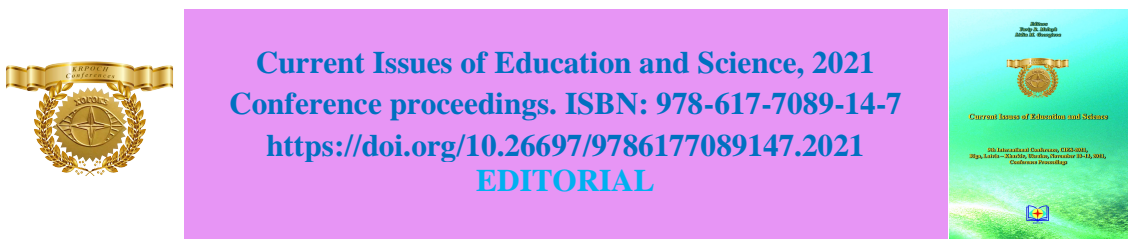

DOI: https://doi.org/10.26697/9786177089147.2021.01

\title{
Message from the Editors of CIES-2021 Conference Proceedings
}

\author{
Yuriy B. MELNYK ${ }^{1,2}$ \\ ${ }^{1}$ Kharkiv Regional Public Organization "Culture of Health" (KRPOCH), \\ ${ }^{2}$ Scientific Research Institute KRPOCH, Ukraine
}

Lidia M. GEORGIEVA ${ }^{3}$

${ }^{3}$ Medical University - Sofia, Bulgaria

Corresponding Author Details

Yuriy B. MELNYK, YBM.office@gmail.com

Received: 15.11.2021; Accepted: 20.11.2021; Published: 17.12.2021

\section{Dear Readers,}

We are honored to publish the Proceedings of the 9th Annual International Conference on Current Issues of Education and Science, Riga, Latvia - Kharkiv, Ukraine, November 10-13, 2021 (CIES-2021).

The aim of the CIES Conference is scientific and practical analysis and systematisation of theoretical and methodological problems that are inherent in the educational process today, as well as development of organisational and methodological recommendations for stakeholders in education and science.

This official international academic event is included in the registers of the Ministry of Education and Science of Ukraine (Reg. No. 538 from 13.01.2021) and Ministry of Health of Ukraine (Reg. No. 387 from 24.12.2020).

CIES-2021 is initiated and supported by Scientific Research Institute Kharkiv Regional Public Organisation "Culture of Health" (Ukraine) and Simcord Information Services (Latvia) with the participation of partner organisations and scientists from 5 continents. 
CIES-2021 Conference Organizing Committee includes the most authoritative scientists from 17 countries, 5 continents in the fields of Education, Psychology, Medicine.

CIES-2021 provides a scientific platform for presenting and discussing new trends and issues in the Social and Behavioral Sciences. 12 revised Conference papers were carefully peer reviewed and selected from 68 submissions. Materials are presented in English and Ukrainian.

CIES-2021 Conference proceedings is intended for professionals and researchers in scientific fields: Education, Psychology, and Health Care Science.

The Conference proceedings provides immediate Open Access to its content on the principle that making research freely available to the public supports a greater global exchange of knowledge. All papers apply under the terms of the Creative Commons Attribution License (CC BY 4.0).

The Conference proceedings are presented in international scientometric databases, repositories and search engines: Crossref System, Google Scholar, EndNote Click (USA); Scilit (Switzerland), etc.

We thank all Authors and Readers of CIES-2021 Conference proceedings and hope for further cooperation.

Take care of yourself and be healthy!

\section{Conflict of interests:}

The authors declare that there is no conflict of interests.

\section{Source of support:}

This research did not receive any outside funding or support.

\section{Information about the authors:}

Melnyk Yuriy Borysovych - https://orcid.org/0000-0002-8527-4638; Doctor of Philosophy in Pedagogy, Associate Professor; Founder and Chairman of the Board, Kharkiv Regional Public Organization "Culture of Health" (KRPOCH); Director, Scientific Research Institute KRPOCH, Kharkiv, Ukraine; Chairman of the CIES-2021 Conference Organizing Committee.

Research interests: education, psychology, psychological technology, culture of health.

Georgieva Lidia Mladenova - https://orcid.org/0000-0002-9320-9203; Doctor of Philosophy in Medicine, MD, Professor, Medical University Sofia, Bulgaria; Member of the CIES-2021 Conference Organizing Committee.

Research interests: social medicine, public health, education. 


\section{Cite this article as:}

Melnyk, Yu. B., \& Georgieva, L. M. (2021). Message from Editors of CIES-2021 Conference proceedings. In Yu. B. Melnyk, \& L. M. Georgieva (Eds.), Current Issues of Education and Science. 9th International Conference, CIES-2021, Riga, Latvia - Kharkiv, Ukraine, November 10-13, 2021, Conference proceedings (pp.4-6). KRPOCH. https://doi.org/10.26697/9786177089147.2021.01

\section{Copyright information:}
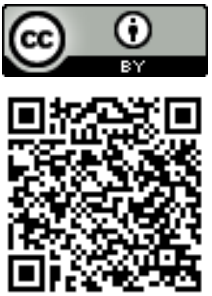

The published paper are licensed under a Creative Commons "Attribution" 4.0 Worldwide

The electronic version of this article is complete. Full or partial reproduction of article is allowed, citing to the source, author(s) and DOI. An electronic copy of the Conference proceedings in open access is available via the KRPOCH Publishing website https://publisher.culturehealth.org 